\title{
Intensity of Vascular Streak Dieback in Different Cocoa Clones and Various Agro-Climatic Conditions
}

\author{
Indah Anita-Sari ${ }^{1)}$, Agung Wahyu Susilo ${ }^{1)}$, Niken Puspita Sari ${ }^{1)}$, Febrilia Nur 'Aini ${ }^{1)}$, Bayu \\ Setyawan $^{1)}$, Peter McMahon ${ }^{2)}$, and Philip Keane ${ }^{3)}$ \\ ${ }^{1)}$ Indonesian Coffee and Cocoa Research Institute, J1. PB Sudirman No. 90, Jember 68118, Indonesia \\ ${ }^{2}$ University of Sydney, 410 Elizabeth Street, Camperdown, NSW 2006, Australia \\ ${ }^{3}$ La Trobe University, Bundoora, Melbourne, VIC 3086, Australia
}

\begin{abstract}
Vascular streak dieback (VSD) is one of the main diseases on cocoa. This disease can produce a heavy damage in susceptible plants. Agro-climatic condition influences the VSD disease severity level. A study on the relationship between agro-climatic condition and VSD disease severity was conducted in eight locations which were selected based on difference in agro-climatic conditions including altitude, rainfall, number of wet, and dry months. Randomized complete block design was used consisting of eight agro-climatic conditions as treatments which consisted of 200 trees samples, and scored for VSD intensity. A study was also conducted on the response of cocoa clones with different level of resistance at different altitude at Kendeng Lembu, Jatirono, Sungai Lembu, Banjarsari, and Sumber Asin Plantations. A split plot design was applied consisting of two factors. The first factor was location including Pager Gunung (highland) and Besaran (lowland). The second factor was clone resistance with two levels: PA 191 (resistant) and BL 703 (susceptible). VSD scores and stomatal characteristics (stomata number, stomata diameter, and stomata aperture) were determined. The results of experiment showed that VSD scoring differed significantly between the eight agro-climatic conditions. The highest VSD score occurred in the lowland (Gereng Rejo, Banjarsari Plantation, $38 \mathrm{~m}$ asl.), where the average annual rainfall was $2161 \mathrm{~mm}$, with five dry months. Cocoa trees in Sumber Asin $(580 \mathrm{~m}$ asl.), with the average annual rainfall of $2302 \mathrm{~mm}$ and 8.5 wet months/3.5 dry months were mostly free of VSD disease. Altitude was positively correlated with rainfall, and negatively correlated with VSD severity. Number of wet months was negatively correlated with VSD severity. Conversely, number of dry months was positively correlated with VSD. The result indicated that genotype, environment, or their interaction did not significantly affect number and aperture of stomata. Although stomatal diameter was significantly affected by environment, genotypes or their interaction with environment did not influence this character.
\end{abstract}

Keywords: Vascular streak dieback, Theobroma cacao, clone, disease intensity/severity, agro-climatic conditions, altitude

\section{INTRODUCTION}

VSD (vascular streak dieback) is one of the main diseases of cocoa. The causal pathogen, Ceratobasidium theobromae (syn. Oncobasidium theobromae) has infected cocoa (Theobroma cacao L.) in almost all provinces in Indonesia. Sudarmadji \& Pawirosoemarjo (1990) reported that VSD development was influenced by environmental conditions, including high seasonal rainfall and humidity that generally found under climate 
types A and B according to Schmidt \& Ferguson classification. VSD infection is associated with high humidity and moderate night-time temperatures: under these conditions the pathogen produces basidiospores, which are dispersed by wind up to $100 \mathrm{~m}$ (Keane, 1981) resulting in new infections via young leaves (Keane et al., 1972; Purwanti, 2011). Agro-climatic difference can influence the disease level in the plants (Chakraborty et al., 2000). Different agroclimatic conditions relate to suitability of the environment of the pests and diseases. Management of pests, diseases and weeds needs to be practised according to particular, local climatic conditions (Howden \& White, 2007). Changes in environmental conditions strongly correlate with yield losses level caused by disease either directly or indirectly (Burdon et al., 2006; Garrett et al., 2006; Crowl et al., 2008; Eastburn et al., 2011).

Severity of VSD is also influenced by the level of plant resistance. The VSD disease severity in resistant clones is lower than in susceptible clones under the same environmental conditions (Anita-Sari \& Susilo, 2012). The performance of plant is determined by genetic and environmental factors and their interaction. Plant performance reflects the interaction between genotype and environment. Investigating the influence of genotype and environment interaction could be done by testing genetic varieties under various environmental conditions (Trustinah \& Iswanto, 2013). In suitable environments, the plants may perform well with a positive response to pests and diseases.

The strategy of disease management depends on particular climate conditions. Climatic changes can also lead to the spread of disease to other geographical areas. Morphological and physiological characters in plants may also vary according to the environment (Ghini et al., 2008). Suitability indicators related to microclimate conditions include anatomy characteristics, including stomata characteristies (Barber et al., 2004; Gitz \& Baker, 2009; Avramov et al., 2007). Stomatal function may depend on the intensity of light conditions. The number and size of stomata are strongly influenced by genotype and environmental factors (Munir et al., 2011). For example, stomatal density has been shown to decrease with decreasing light intensity (Avramov et al., 2007). Preliminary research results indicated that the stomatal characteristics can be used as selection criteria for VSD resistance. Stomatal number and aperture were shown to be lower in resistant clones than in susceptible clones (Anita-Sari \& Susilo, 2013). However, in suitable environments, even susceptible clones will show good growth and productivity and low VSD severity. A study on the influence of genotype, environment and their interaction reported here provides information about the suitability of genotypes to particular locations in which VSD is prevalent.

\section{MATERIALS AND METHODS}

The research was conducted in eight locations which selected based on differences of agro-climatic conditions, in particular altitude, rainfall, number of wet months, and number of dry months (Table 1). A randomized complete block design consisting of eight agro-climatic conditions as treatments was applied. Each treatment consisted of 200 trees that planted in 2006/2007 with $3 \mathrm{~m} \mathrm{x} 3 \mathrm{~m}$ space. Leucaene sp. was used as permanent shading in this location. VSD scoring was conducted according to Susilo \& Anita-Sari (2011) using a 0-6 scale, where 0 indicated no detectable disease and 6 indicated severe symptoms. Data analysis was conducted using SAS 9.1 and Excel 2010. Analysis of variance was done with the $\mathrm{F}$ test (Table 2) 
Table 1. Research locations with various agro-climatic condition

\begin{tabular}{lcccc}
\hline & Altitude (m asl.) & Rainfall (mm/year) & \multicolumn{2}{c}{ Number of/year } \\
\cline { 3 - 5 } Location & & & wet months & dry months \\
\hline Gunung Raung-Jatirono & 490 & 2532 & 8.6 & 2.5 \\
Sumber Baru-Jatirono & 410 & 2532 & 8.6 & 2.5 \\
Pager Gunung-Kendeng Lembu & 262 & 2167 & 7.3 & 3.3 \\
Kaliputih-Kendeng Lembu & 130 & 2167 & 7.3 & 3.3 \\
Pacauda-Sungai Lembu & 4 & 2233 & 6.5 & 4.2 \\
Antokan-Banjarsari & 232 & 2161 & 6.4 & 5.0 \\
Banjarsari- Banjarsari & 104 & 2161 & 6.4 & 5.0 \\
Gerengrejo-Banjarsari & 38 & 2161 & 6.4 & 5.0 \\
Sumber Asin & 580 & 2302 & 8.5 & 3.5 \\
\hline
\end{tabular}

Table 2. Analysis of Variance for split plot design

\begin{tabular}{lcc}
\hline Source of variance & $\mathrm{df}$ & Mean square \\
\hline Main factor & $\mathrm{r}-1$ & MS Block \\
Block & $\mathrm{a}-1$ & MS A \\
Factor A & $(\mathrm{a}-1)(\mathrm{r}-1)$ & MSG a \\
Error a & & MS B \\
\hline Sub factor & $\mathrm{b}-1$ & MS AB \\
Factor B & $(\mathrm{a}-1)(\mathrm{b}-1)$ & MSG b \\
Interaction AB & $\mathrm{A}(\mathrm{r}-1)(\mathrm{b}-1)$ & \\
Error b & &
\end{tabular}

Source: Gasperz (1991)

and significance between means detected with the Duncan multiple range test (DMRT) at $\alpha 5 \%$ significant level.

The research was conducted at Kendeng Lembu Plantation, PTPN XII using a split plot design consisting of two factors: 'location' including Pager Gunung (highland) and Besaran (lowland) and cocoa genotype (or clone) with two levels of resistance to VSD: PA 191 (resistant) and BL 703 (susceptible) (Anita-Sari \& Susilo, 2014). VSD scores and stomatal characteristics (number of stomata, stomata diameter, stomata aperture) were determined. Stomatal measurements were conducted according to Anita-Sari \& Susilo (2012).Data analysis was conducted using the SAS 9.1 program. Analysis of variance was conducted using the $\mathrm{F}$ test and means separated with the DMRT at $\alpha 5 \%$ level of probability.

\section{RESULTS AND DISCUSSION}

The results of the study indicated that while average VSD severity was not high in any of the locations (in 2011), there were differences in VSD severity level between different agro-climatic conditions (Table 3). The highest VSD score (1.78) was recorded at lowland of Gereng Rejo, Banjarsari plantation with an altitude of $38 \mathrm{~m}$ asl., an average annual rainfall of about $2161 \mathrm{~mm}$ and five annual dry months. On the other hand, at highland of Sumber Asin Experimental Station of ICCRI at $580 \mathrm{~m}$, an average annual rainfall of $2302 \mathrm{~mm}$, and 8.5 wet months and 3.5 dry months annually, was free of VSD disease.

The occurrence of disease epidemics is influenced by interaction between plant, pathogen and environment, particularly agroclimatic conditions (Abadi, 2000). The high rainfall at Banjarsari plantation in 2011 
Table 3. VSD scores on different agro-climatic conditions difference

\begin{tabular}{lc}
\hline Location (farm-plantation) & VSD Scores \\
\hline Sumber Baru-Jatirono & $1.14 \mathrm{c}$ \\
Pager Gunung-Kendeng Lembu & $0.82 \mathrm{f}$ \\
Kaliputih-Kendeng Lembu & $1.46 \mathrm{~b}$ \\
Pacauda-Sungai Lembu & $0.88 \mathrm{ef}$ \\
Antokan-Banjarsari & $0.90 \mathrm{ef}$ \\
Banjarsari-Banjarsari & $0.95 \mathrm{de}$ \\
Gerengrejo-Banjarsari & $1.78 \mathrm{a}$ \\
Sumber Asin & $0.00 \mathrm{~g}$ \\
\hline
\end{tabular}

Note: Numbers within a column with the same letter are not significantly different at the 5\% level according to DMRT.

Table 4. Correlation between agro-climate parameters and VSD severity

\begin{tabular}{lcc}
\hline Correlation & Correlation value & Note \\
\hline Altitude vs rainfall & 0.71 & Significant \\
Altitude vs VSD score & -0.72 & Significant \\
Rainfall vs VSD score & -0.20 & Not signifcant \\
Number of wet months vs VSD score & -0.59 & Significant \\
Number of dry months vs VSD score & 0.31 & Not significant \\
\hline
\end{tabular}

resulted in a higher VSD severity level than at Kalisepanjang, although more basidiospores of Ceratobasidium theobromae were found at Kalisepanjang than at Banjarsari (Purwanti, 2011). High rainfall and humidity increased rates of VSD disease infection occur (Purwanti, 2007; Sudarmadji \& Pawirosoemarjo, 1990). Development of VSD infection was influenced by humidity and low temperature which affect the pathogens could produce basidiospores and germinate (Purwanti, 2011). Meanwhile, the results of this research showed that not only rainfall factor which influenced VSD disease attacks, but also the altitude, number of dry months, and number of wet months could influence the VSD disease level.

Altitude was significantly correlated with rainfall $(r=0.71)$. In contrast, altitude had a negative correlation with VSD disease attacks $(r=-0.72)$ (Table 4). In high rainfall area, triacontanol translocation can not be done in the plants because the high humidity will cause low transpiration and assimilate translocation will be hampered (Wandana \& Hanum, 2012).
Average VSD disease intensity has been shown to be higher in the lowlands than the highlands (Anita-Sari \& Susilo, 2014). This is in line with Ghini et al. (2008) who reported that cereal crops also showed lower disease severity in higher, compared to lower, growing areas due to differences of physiological and anatomical characters which was an adaptation form of plants resulted in difference response of the plants to VSD disease.

Total rainfall was negatively correlated with VSD disease severity $(r=-0.20)$. Agro-climate conditions, such as humidity, rainfall (duration and intensity), relative humidity, dew, leaf wetness level (duration and intensity, water splash, and rain water flow) could affect the VSD level (Keane, 1981; Dennis, 1990; Purwanti, 2011). The results of this study showed that number of wet months and VSD disease severity had a significant negative correlation $(\mathrm{r}=$ -0.59) and, conversely, number of dry months had positive correlation with VSD disease $(r=0.31)$.

Environmental conditions often influence disease levels because they affect the ability 
of pathogens to reproduce, disperse, and initiate new infections. The key environmental factors include humidity, rainfall, wind and temperature (Sinaga, 2003). Regression analysis results (Figure 1) showed that the climatic factors, among others the amount of rainfall, number of wet months and altitude influenced average VSD disease severity. In particular, a decrease number of wet months was related to increase in VSD disease.

Semangun (1996) reported that high intensity of rainfall and humidity could help the pathogens to spread their inoculum and, therefore, increase disease severity. In present study, the results were related to the impact of Ceratobasidium theobromae on plant function, particularly transport in xylem vessels. In dry condition, blockage of water transport resulted in increased severity of the disease. At high rainfall, even where the fungus causes partial blockage of the xylem, sufficient water is available for normal photosynthesis and transpiration, and other physiological processes necessary to plants.

This study showed that level of VSD severity was significantly influenced by genotype, environment and their interaction. However, stomatal number and aperture were not significantly affected by genotype, environment and their interaction. Meanwhile, stomata diameter showed significant differences in different environments but not between different genotypes. In addition, no interaction between genotype and environment occurred (Table 5). Plant adaptation to the environment may be achieved by changing
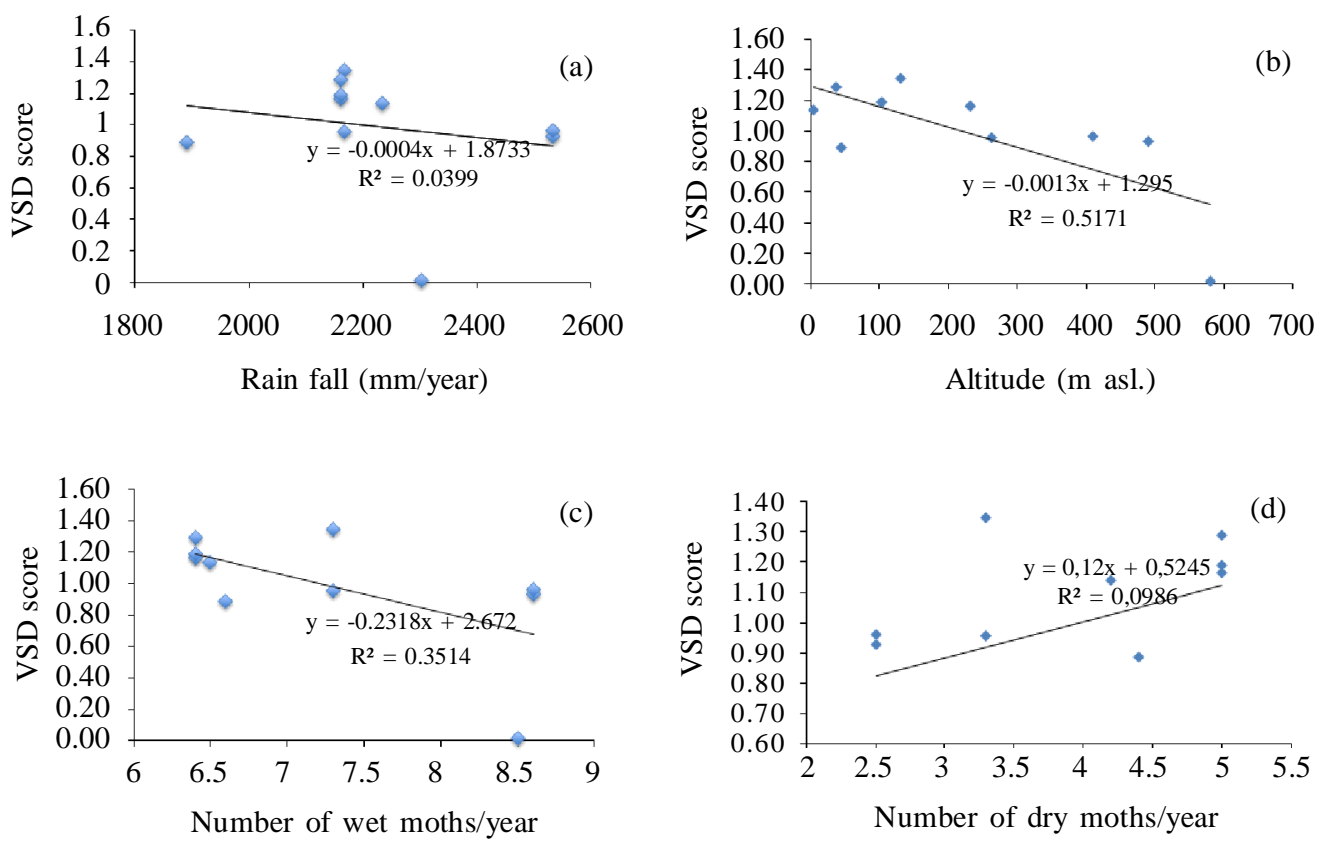

Figure 1. Relationship between some climatic factors (a) rainfall (mm), (b) altitude ( $\mathrm{m}$ asl.), (c) number of wet months, (d) number of dry months and VSD disease level 
phenotypical characters, including those related to plant anatomy, morphology, physiology and biochemical processes. Phenotypic alterations may occur as response to climate condition, such as phenotypic differences on plant which found at different altitude (Misra \& Srivastava, 2006; Purohit, 2003). Morphological changes associated with plant competition on a good environment, in the otherhand physilogical changes associated with a less productive environment (Misra \& Srivastava, 2006).

VSD severity level of PA 191 was significantly lower than in BL 703 (Table 6). The resistant clone (PA 191) performed better compared with the susceptible clone (BL 703) regardless of the climatic conditions. According to Suryotomo (2006), resistant clones might have the ability to inhibit pathogen development, so the pathogens could not reproduced and spread. Plant response to pathogens was influenced by genetic and environmental factors. Plant ability to against the diseases depended on its susceptibility and resistance. Disease severity level depended on nature factor, environment and growth location.
Stomata number, diameter and aperture did not significantly differ between the resistant clone (PA 191) and the susceptible clone (BL 703) (Table 6). Nevertheless, higher stomata number, diameter, and apertures were recorded in BL 703 than in PA 191, although larger sample sizes would be needed to verify these higher values. VSD disease severity and stomata diameter were both significantly different between the two different altitudes. VSD disease severity at Pager Gunung Farm (highland) with the agroclimatic conditions shown in Table 1 was lower than at Besaran Farm (lowland). In contrast, the stomatal diameter in Besaran Farm was lower than in Pager Gunung Farm. The number of stomata and stomatal aperture did not significantly different between the two locations.

Analysis results showed that altitude influenced VSD disease severity level in both clones tested (Table 6). VSD disease severity in BL 703 was higher than in PA191 in both environments. However, in the two clones tested in Pager Gunung Farm, VSD disease severity was lower than in the lowland

Table 5. Mean square of number, diameter and opening width of stomata in different genotypes and altitudes

\begin{tabular}{|c|c|c|c|c|c|}
\hline \multirow{2}{*}{ Source of variance } & \multirow{2}{*}{$\mathrm{df}$} & \multirow{2}{*}{ VSD score } & \multicolumn{3}{|c|}{ Stomata } \\
\hline & & & Number & Diameter $(\mu \mathrm{m})$ & Aperture $(\mu \mathrm{m})$ \\
\hline Genotype & 1 & $9.01^{*}$ & 829.197 ns & $8.33^{\mathrm{ns}}$ & $0.676^{\mathrm{ns}}$ \\
\hline Environment (altitude) & 1 & $0.88^{*}$ & 477.052 ns & $117.81^{*}$ & $0.533^{\mathrm{ns}}$ \\
\hline Genotype $\mathrm{x}$ Environment & 1 & $0.51^{*}$ & $1,039.392$ ns & $9.36^{\mathrm{ns}}$ & $0.686^{\mathrm{ns}}$ \\
\hline Replication & 2 & $0.16^{*}$ & 18.372 ns & $3.87 \mathrm{~ns}$ & $0.055^{\mathrm{ns}}$ \\
\hline
\end{tabular}

Note: Fisher test indication significant ${ }^{*}$ and not significantly different ns) at $\alpha=5 \%$

Tabel 6. Influence of genetic and environment factors on number, diameter and width of open stomata

\begin{tabular}{lcccc}
\hline & VSD score & Stomata number & Stomata diameter $(\mu \mathrm{m})$ & Stomatal aperture $(\mu \mathrm{m})$ \\
\hline Clones & $0.23 \mathrm{~b}$ & $1,345 \mathrm{a}$ & $7.32 \mathrm{a}$ & $1.04 \mathrm{a}$ \\
PA 191 & $1.96 \mathrm{a}$ & $1,870 \mathrm{a}$ & $8.98 \mathrm{a}$ & $1.51 \mathrm{a}$ \\
BL 703 & & & $1.48 \mathrm{a}$ \\
Location & $0.82 \mathrm{~b}$ & $1,408 \mathrm{a}$ & $5.02 \mathrm{~b}$ & $1.06 \mathrm{a}$ \\
Gunung Raung (high land) & $1.37 \mathrm{a}$ & $1,807 \mathrm{a}$ & $\mathrm{a}$ & \\
Besaran (lowland) & & & \\
\hline
\end{tabular}

Note: Numbers within the column with the same letter are not significantly different at $5 \%$ level according to Duncan test. 
location, Besaran Farm. Stomatal diameter in the highland location was greater than in the lowland. Purwanti (2007) reported that VSD could caused heavy damage on susceptible plants because the pathogens in xylem tissue inhibit and reduce nutrients transport to the leaves which causes leaf fall and branch dieback.

Environmental differences including rainfall and altitude affect plant physilogical processes, such as, photosynthesis, transpiration and respiration. Purohit (2003) mentioned that changes in the anatomy, morphology and physiology enable plants to adapt to climatic conditions in different areas and the high $\mathrm{CO}_{2}$ content in order to maintain efficient for development. According to Lakitan (2007), transpiration is influenced by internal and external factors related to stomata aperture, humidity, air temperature and leaf temperature. Purohit (2003) reported that the changes in plant anatomy, morphology and physiology characters was caused by adaptation of the plants at different climate condition.

Statistical analysis showed that VSD intensity had relationship with some environmental variables (Figure 2). The graph divided the variables into two vectors to the right and left. The rate of VSD level leftward along with number of dry months in a location. Its means that number of dry months in a location had positive relationship with the increasing of VSD intensity as shown in Pacauda (Sungai Lembu), Gerengrejo, Banjar Sari and Antokan. Whereas, the environmental variables that

Table 7. VSD scores, stomata number, diameter, and aperture in different clones at two altitudes. Means $( \pm$ SEM) are shown

\begin{tabular}{lcccc}
\hline & VSD scoring & $\begin{array}{c}\text { Stomatal number } \\
\text { per } \mathrm{mm}^{2}\end{array}$ & Stomatal diameter, $\mu \mathrm{m}$ & Stomatal aperture, $\mu \mathrm{m}$ \\
\hline Highland - PA 191 & $0.16 \pm 0.03$ & $1,547.73 \pm 309.48$ & $11.33 \pm 0.97$ & $1.49 \pm 0.10$ \\
Highland - BL 703 & $1.49 \pm 0.10$ & $1,269.43 \pm 112.67$ & $11.23 \pm 2.15$ & $1.48 \pm 0.17$ \\
Lowland - PA 191 & $0.3 \pm 0.03$ & $1,142.46 \pm 258.93$ & $3.30 \pm 1.25$ & $0.59 \pm 0.55$ \\
Lowland - BL 703 & $2.44 \pm 0.16$ & $2,472.23 \pm 429.28$ & $6.73 \pm 1.05$ & $1.54 \pm 0.08$ \\
\hline
\end{tabular}

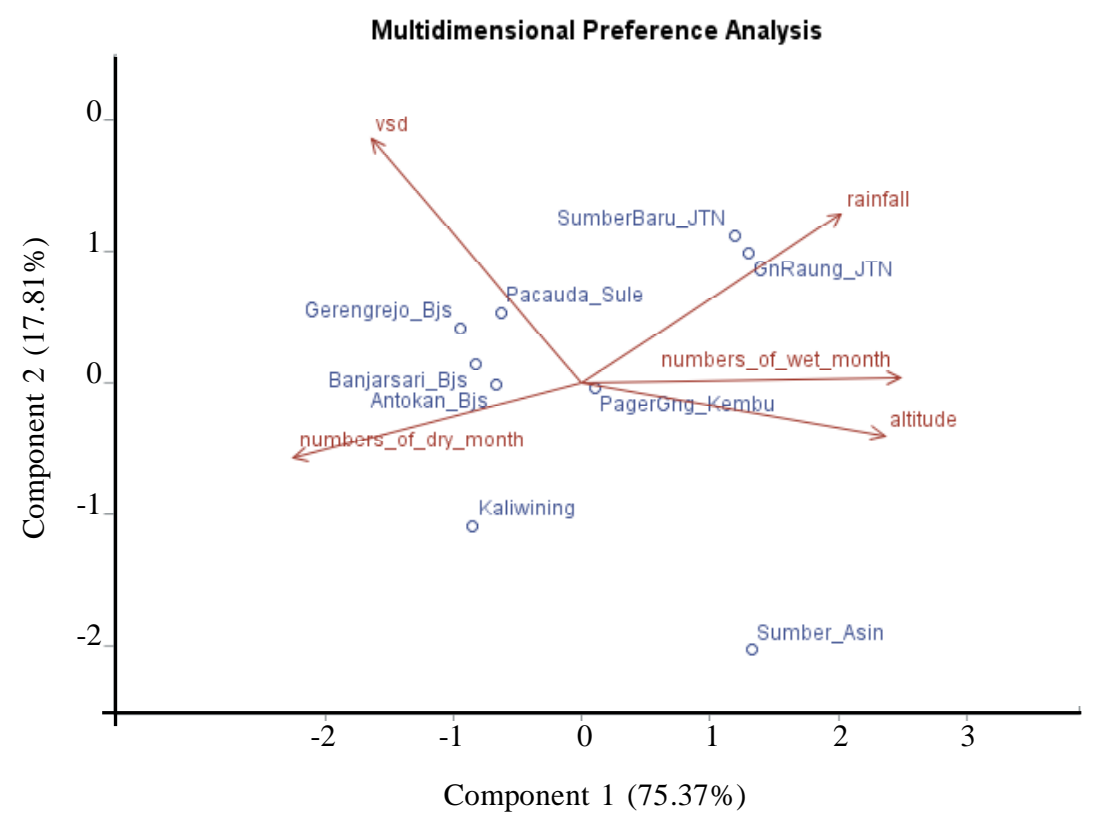

Figure 2. Relationships between VSD level and environment variables in several plantations 
points to the right such as altitude, number of wet months, and rainfall showed that higher values of this environmental variables would give lower VSD intensity as in Pager Gunung, Gunung Raung, and Sumber Baru. Altitude was one of enviromental variable that showed the most close relationship with decreasing of VSD intensity. Higher altitude resulted in lower of VSD intensity as shown in Sumber Asin.

\section{CONCLUSIONS}

Agro-climatic condition influenced VSD disease severity levels in cocoa plants. Altitude and number of wet months were negatively correlated with VSD disease severity, while on the other hand higher number of dry months were linked to increased VSD disease severity levels. Altitude was one of enviromental variable that showed the most close relationship with decreasing of VSD intensity. The different resistance levels of PA 191 and BL 703 resulted in different responses to VSD showed by the alteration of the anatomical characteristics. Agro-climatic condition and disease resistance levels of planting materials should become consideration for cocoa planting

\section{ACKNOWLEDGEMENTS}

The authors would like to acknowledge Director of Indonesian Coffee and Cocoa Research Institute for support of this research. The authorss also thanks for Manager of PTPN XII, Supandi, Sukarmin, and Rudi Hartoyo for their participation in the research observation.

\section{REFERENCE}

Abadi, A.L. (2000). Epidemiologi dan Strategi Pengelolaan Penyakit Tumbuhan. Lembaga Penerbitan Fakultas Pertanian, Universitas Brawijaya, Malang.

Anita- Sari, I. \& A.W. Susilo (2013). Investigation on different characters of stomata on three cocoa clones with resistance level different to vascular streak dieback (VSD) disease. Journal of Agricultural Science and Technology, 3, 41-48.

Anita-Sari, I. \& A.W. Susilo (2014). Effect of genetic and altitude differences on stomatal characters as resistance indicator to VSD (Vascular Streak Dieback) in cocoa (Theobroma cacao L.). Journal of Agricultural Science and Technology, 4, 157-163.

Avramov, S.; D. Pernac \& B. Tucic (2007). Phenotypic plasticity in response to an irradiance gradient in Iris pumila: Adaptive value and evolutionary constraint. Plant Ecology, 190, 275-290.

Barber, J.L.; G.O. Thomas; G. Kerstiens \& K.C. Jones (2004). Current issues and uncertainties in the measurement and modelling of air vegetation exchange and within plant processing of pops. Environmental Pollution, 128, 99-128.

Burdon, J.J.; P.H. Thrall \& A.L. Ericson (2006). The current and future dynamics of disease in plant communities. Annual Review Phytopathology, 44, 19-39.

Chakraborty, S.; A.V. Tiedemann \& P.S. Teng (2000). Climate change: Potential impact on plant diseases. Environmental Pollution, 108, 317-326.

Crowl, T.A.; T.O. Crist; R.R. Parmenter; G. Belovsky \& A.E. Lugo (2008). The spread of invasive species and infectious disease as drivers of ecosystem change. Frontiers Ecology Environment, 6, 238-246. 
Eastburn, D.M.; A.J. McElrone \& D.D. Bilgin (2011). Influence of atmospheric and climatic change on plant-pathogen interactions. Plant Pathology, 60, 54-69.

Garrett, K.A.; S.P. Dendy; E.E. Frank; M.N. Rouse $\&$ S.E. Travers (2006). Climate change effects on plant disease: genomes to ecosystems. Annual Review Phytopathology, 44, 489-509.

Ghini, R.; E. Hamada \& W. Bettiol (2008). Climate change and plant disease. Science Agriculture, 65, 98-107.

Gitz, D.C. \& J.T. Baker (2009). Methods for creating stomata impressions directly onto archivable slides. Agronomy Journal, 101, 232-236.

Keane, P.J. (1981). Epidemiology of vascular streak dieback of cocoa. Annals of Aplied Biology, 98, 227-241.

Misra, A. \& N.K. Srivastava (2011). Altituderelated changes in activities of carbon metabolism enzymes and secondary plant products menthoforon an active pharmaceutical constituents yield in pippermint (Menthapiperita L. var. Kukarail). African Journal of Pharmacy and Pharmacology, 5, 1983-1989.

Lakitan, B. (2007). Dasar-dasar Fisilogi Tumbuhan. Raja Grafindo Persada, Jakarta.

Munir, M.; M.A. Khan; M. Ahmed; A. Bano; S.N. Ahmed \& K. Tariq (2011). Foliar epidermal anatomy of some ethno botanically important species of wild edible fruits of Northern Pakistan. Journal of Medicinal Plants Research, 5, 5873-5880.

Purohit, A.N. (2003). Plant form and functional behaviour along the altitudinal gradient in mountains. Journal Plant Biology, 30, 199-209.

Purwanti, E. (2011). Hubungan Kepadatan Inokulum dengan Intensitas Penyakit
VSD pada Pertanaman Kakao di Dua Lokasi Kebun Wilayah PTPN XII. Skripsi, Universitas Jember, Jember.

Semangun, H. (1996). Pengantar Ilmu Penyakit Tumbuhan. Gadjah Mada University Press, Yogyakarta.

Sinaga, M.S. (2003). Dasar-dasar Ilmu Penyakit Tumbuhan. Seri Agriteks, Penerbar Swadaya, Jakarta.

Sudarmadji, D. \& S. Pawirosoemardjo (1990). Hama dan penyakit, kendala utama dalam pengembangan kakao di Indonesia, In: S. Pawirosoemardjo; D. Sudarmadji; Harsono \& Inggriani S. Basuki (Eds.). Perlindungan Tanaman Menunjang Terwujudnya Pertanian Tangguh dan Kelestarian Lingkungan. PT. Agricon, Bogor.

Suryotomo, B. (2006). Ketahanan alami beberapa genotipe cabai (Capsicum annuum L.) terhadap penyakit antraknosa. Jurnal Sains dan Teknologi Indonesia, 8, 1, 1-6.

Susilo, A.W. \& I. Anita-Sari (2011). Respon beberapa hibrida kakao (Theobroma cacao L.) tahan terhadap Vascular Streak Dieback. Pelita Perkebunan, 27, 77-87.

Trustinah \& R. Iswanto (2013). Pengaruh interaksi genotipe dan lingkungan terhadap hasil kacang hijau. Penelitian Pertanian Tanaman Pangan, 32, 36-42.

Wandana, S.; C. Hanum \& R. Sipayung (2012). Pertumbuhan dan hasil ubi jalar dengan pemberian pupuk kalium dan triakontanol. Jurnal Online Agroekoteknologi, 1, 199-211.

White, D.H. \& S.M. Howden (2007). Climate and its effects on crop productivity and management. Soils, Plant Growth and Crop Production, 1, 1-9.

$$
* * 0 * *
$$

